\title{
Chemical constituents of Pseudobrickellia brasiliensis leaves(Spreng.) R.M. King \& H. Rob. (Asteraceae)
}

DE AMORIM, M.L.L.'; GODINHO, W.M.'; ARCHANJO, F.C.1; GRAEL, C.F.F.1*

1Universidade Federal dos Vales do Jequitinhonha e Mucuri - Departamento de Farmácia, Faculdade de Ciências Biológicas e da Saúde, Campus JK - Rodovia MGT 367 - Km 583, n॰ 5000, Bairro Alto da Jacuba, 39.100-000, Diamantina - MG, Brasil. ‘Autor para correspondência: cris.grael@ufvjm.edu.br

\begin{abstract}
Pseudobrickelliabrasiliensisis aspecies endemic toBrazil, popularlyknown as "arnica"/ "arnica-do-campo"/ "arnica-do-mato" and used for itsanalgesicand antiinflammatoryproperties. The objective of this research was thephytochemical studyof the essential oilandhexaneandethyl acetateextracts of the leaves of this species. The essential oilwasextracted byhydrodistillation using a Clevengerapparatusand was analyzed byGC/MS, 25components were identified, with a predominance ofmonoterpenes. The extractswere subjected toclassicalchromatographyand the fractionswere analyzed byGC/ MS, 1D ${ }^{1 H}$-NMR, ${ }^{13} \mathrm{C}-\mathrm{NMR}$ and ${ }^{13} \mathrm{C}$-NMR-DEPT 135 . $\alpha$-amyrin, $\alpha$-amyrin acetate, $\beta$-amyrin, $\beta$-amyrin acetate, lupeol, lupeolacetate, pseudotaraxasterol andtaraxasterol (triterpenes), andkaurenoicacid (diterpene) were identified.Theseterpenesarechemo-taxonomicallyrelated to theEupatorieaetribe(Asteraceae) and may be responsible for the anti-inflammatory activity attributed to the plant.
\end{abstract}

Key words: Pseudobrickellia brasiliensis, Asteraceae, medicinal plant, phytochemistry, terpenes.

\begin{abstract}
RESUMO: Constituintes químicos das folhas de Pseudobrickellia brasiliensis (Spreng.) R.M. King \& H. Rob. (Asteraceae). Pseudobrickellia brasiliensis é uma espécie endêmica do Brasil, popularmente conhecida como "arnica"/ "arnica-do-campo"/ "arnica-do-mato" e usada por suas propriedades analgésica e antiinflamatória. O objetivo do trabalho foi o estudo fitoquímico do óleo essencial e dos extratos hexânico e em acetato de etila das folhas dessa espécie. $O$ óleo essencial foi extraído por hidrodestilação em aparato de Clevenger e foi analisado por CG/ EM, sendo identificados 25 componentes, com predomínio de monoterpenos. Os extratos foram submetidos a cromatografia clássica, e as frações foram analisadas por CG/EM, 1D ${ }^{\prime} H-R M N$, ${ }^{13} \mathrm{C}$-RMN e ${ }^{13} \mathrm{C}$-RMN-DEPT 135. Foram identificados $\alpha$-amirina, acetato de $\alpha$-amirina, $\beta$-amirina, acetato de $\beta$-amirina, lupeol, acetato de lupeol, pseudotaraxasterol e taraxasterol (triterpenos) e o ácido caurenóico (diterpeno). Estes terpenos estão quimiotaxonomicamente relacionados a tribo Eupatorieae (Asteraceae) e podem ser responsáveis pela atividade antiinflamatória atribuída a planta.
\end{abstract}

Palavras-chave: Pseudobrickellia brasiliensis, Asteraceae, planta medicinal, fitoquímica, terpenos.

\section{INTRODUCTION}

The "arnica" or "arnica-do-campo" or "arnica-do-mato" plant (Pseudobrickellia brasiliensis (Spreng.) R.M. King \& H. Rob.) is a shrub or subshrub species, belonging to the Eupatorieae tribe, Asteraceae family. It is endemic to Brazil and is observed in "campo rupestre" and "cerrado" regions in the States of Minas Gerais, São Paulo, Goiás, Mato Grosso, Pernambuco, and Bahia (Almeida et al., 2004; Forzza et al., 2010).
The whole plant or parts of the plant are popularly used as an analgesic and an antiinflammatory and topical wound healer in a tanned or macerated form in alcohol (Ribeiro et al., 2001; Silva et al., 2015).

Despite its medicinal use, $P$. brasiliensis has not been widely studied until now except two phytochemical studies: a research for the ether extract of its aerial parts, which was reported to 
contain sesquiterpenes (4ß-hydroxygermacra-1(10), 5-diene, spathulenol, $y$-cadinene, $\alpha$-cadinol, and oplopanone) and triterpenes (lupeol, isomer $\Delta^{12}$ of lupeol, $\beta$-amyrin acetate, $11 \alpha$-hydroxy- $\alpha$-amyrin, and $11 \alpha$-hydroxy- $\beta$-amyrin) in its composition (Bohlmann et al., 1984) and another study of essential oil was obtained from plants collected in another region (Araçuai-MG) in winter at the beginning of flowering time. In this previous study, the essential oil presents the predominance of monoterpenes with the main ones being terpinen-4-ol, $y$-terpinene, $\alpha$-terpinene, and $\alpha$-terpineol (Silva et al., 2015).

Therefore, considering the sparse reports of the chemical composition of $P$. brasiliensis, this study was conducted to contribute to the phytochemical study of this species by identifying the chemical components in the essential oil and hexane and ethyl acetate extracts as obtained from its leaves.

\section{MATERIAL AND METHOD}

\section{Plant material}

The leaves of Pseudobrickellia brasiliensis (Spreng.) R.M.King \& H. Rob.(Asteraceae) were collected in vegetative stage in the "campo rupestre" located on the JK Campus of the Universidade Federal dos Vales do Jequitinhonha e Mucuri (UFVJM), Municipality of Diamantina, Minas Gerais, Brazil (18 $12.164^{\prime}$ S and 4334.398' W; altitude 1384 $\mathrm{m}$ ) in April 2010 (autumn). Taxonomic identification was performed by Prof. Dr. Aristônio M.Teles and vouchers were deposited under numbers 1096 and 1296 at the DIAM Herbarium of the UFVJM.

\section{General experimental procedures}

Gas chromatography (GC) analyses were performed using a Shimadzu $®$ GC-MS QP2010 model equipment using a mass spectrometer as detector (GC/MS), where the following conditions were employed, depending on the fraction to be analyzed:

A) Analysis of the essential oil - Agilent $₫ \mathrm{DB}$ $5 \mathrm{MS}$ capillary column $(30 \mathrm{~m} \times 0.25 \mathrm{~mm} \times 0.25 \mu \mathrm{M})$; oven temperature program: 60 to $240^{\circ} \mathrm{C}\left(3^{\circ} \mathrm{C} \mathrm{min}-1\right)$; injector temperature: $250^{\circ} \mathrm{C}$; carrier gas: helium set at a flow rate of $1.33 \mathrm{ml} \mathrm{min}^{-1}$ and a pressure of 81.90 $\mathrm{kPa}$; ionization mode: electron ionization at $70 \mathrm{eV}$.

B) Analysis of the chemical constituents found in the organic extracts (hexane and ethyl acetate extracts) - a) Agilent ${ }^{\circledR}$ DB-5MS capillary column $(30 \mathrm{~m} \times 0.25 \mathrm{~mm} \times 0.25 \mu \mathrm{M})$; oven temperature program: heated to $280{ }^{\circ} \mathrm{C}\left(6^{\circ} \mathrm{C}\right.$ $\left.\mathrm{min}^{-1}\right)$ and maintained at $280^{\circ} \mathrm{C}(20 \mathrm{~min})$; injector temperature: $260^{\circ} \mathrm{C}$; carrier gas: helium set at a flow rate of $1.50 \mathrm{ml} \mathrm{min}^{-1}$ and a pressure of $182.20 \mathrm{kPa}$; ionization mode: electron ionization at $70 \mathrm{eV}$. Or b)
Agilent ${ }^{\circledR}$ DB-17MS capillary column $(30 \mathrm{~m} \times 0.25$ $\mathrm{mm} \times 0.25 \mu \mathrm{M}$ ); oven temperature program: $120^{\circ} \mathrm{C}$ to $260{ }^{\circ} \mathrm{C}\left(20^{\circ} \mathrm{C} \mathrm{min}-1\right)$ maintained at $260{ }^{\circ} \mathrm{C}$ for 5 min, increased from $260^{\circ} \mathrm{C}$ to $280^{\circ} \mathrm{C}\left(2{ }^{\circ} \mathrm{C} \mathrm{min}{ }^{-1}\right)$ maintained at $280^{\circ} \mathrm{C}$ for $9 \mathrm{~min}$, increased from 280 ${ }^{\circ} \mathrm{C}$ up to $290{ }^{\circ} \mathrm{C}\left(2{ }^{\circ} \mathrm{C} \mathrm{min}-1\right)$ maintained at $290{ }^{\circ} \mathrm{C}$ for $20 \mathrm{~min}$ ); injector temperature: $260{ }^{\circ} \mathrm{C}$; carrier gas: helium set at a flow rate of $1.40 \mathrm{~mL} \mathrm{~min}^{-1}$ and a pressure of $114.10 \mathrm{kPa}$; ionization mode: electron ionization at $70 \mathrm{eV}$.

The essential oil constituents were identified by comparing the relative retention index (RRI) and the mass spectrum of each constituent with data available in the literature (Adams, 2001; Babushok \& Zenkevich, 2009) and the Wiley $7 \AA$ spectra database, respectively. The minimum similarity index (SI) adopted in the comparison of mass spectra of essential oil components and the spectra database was eighty-nine. RRI calculations were performed by the interpolation of retention times with a homologous series of hydrocarbons $\left(\mathrm{C}_{9}-\mathrm{C}_{24}\right)$-Alltech ${ }^{\circledast}$, as proposed by Van Den Dool \& Kratz (1963).

In the specific case of the terpenes, 5 - $\alpha$-cholestane (Sigma $\AA$ ) was used as internal standard to calculate the RRIs. The calculated RRIs were compared with those observed for a series of terpene standards, as described in the literature (Gonçalves et al., 2011). The terpene standards used were previously isolated from extracts of various plants and identified by ${ }^{1} \mathrm{H}-\mathrm{NMR}$ and ${ }^{13} \mathrm{C}-\mathrm{NMR}$ (presented good degree of purity) and are deposited at the Núcleo de Pesquisa em Produtos Naturais e Sintéticos, da Faculdade de Ciências Farmacêuticas de Ribeirão Preto -USP (SP, Brazil).

The relative areas (\%) of each individual peak from the GC/MS chromatograms were proportional to the total ion current without standardization.

For the column chromatography (CC), Vetec ${ }^{\circledR}$ silica gel 60 (35 -70 mesh) was used as the stationary phase, and n-hexane, ethyl acetate (EtOAc), ethanol (EtOH), and mixtures of these solvents were used as the mobile phase in an increasing gradient of polarity.

The chromatographic profiles were established by thin layer chromatography (TLC), performed on chromatography plates on an aluminum support and silica gel 60 with a fluorescent indicator (Macherey-Nagel $\circledast$ - $U V_{254}$ ) using the eluent systems of various polarities and ultraviolet light ( $\lambda 255$ and $366 \mathrm{~nm}$ ), sulfuric vanillin, and/or iodine vapor as developing agents.

Nuclear magnetic resonance spectra (1D ${ }^{1} \mathrm{H}-\mathrm{NMR},{ }^{13} \mathrm{C}-\mathrm{NMR}$, and ${ }^{13} \mathrm{C}-\mathrm{NMR}$-DEPT 135) were recorded on a Bruker ${ }^{\circledR}$ Avance DPX-200 spectrometer, operating at $200 \mathrm{MHz}$ for ${ }^{1} \mathrm{H}$ and 50 $\mathrm{MHz}$ for ${ }^{13} \mathrm{C}$ NMR. Chemical shifts $\left(\delta_{\mathrm{H}}\right.$ and $\left.\delta_{\mathrm{C}}\right)$ were 
obtained in ppm, with the TMS signal as an internal reference using $\mathrm{CDCl}_{3}($ Aldrich $®)$ as the solvent.

\section{Essential oil extraction}

Previously grated fresh leaves of $P$. brasiliensis $(84.49 \mathrm{~g})$ were subjected to hydrodistillation for about $2 \mathrm{~h}$ using a Clevenger apparatus. The oil obtained had a lower density than water. The obtained oil was separated from the water, dried (by percolation in a simple filtering system containing anhydrous sodium sulfate Synth $\left(\right.$ ), maintained at $-20{ }^{\circ} \mathrm{C}$, and protected from light until analysis. Distillation yielded $0.002 \%$ $(\mathrm{v} / \mathrm{w})$ of a slightly yellow oil with a distinctive odor. The yield calculation was performed by relating the obtained oil volume (measured directly in Clevenger apparatus) with the mass of plant material used in the extraction. The chemical composition of the oil was determined by GC/MS.

\section{Obtaining hexane and ethyl acetate extracts and fractionation to identify chemical constituents}

P. brasiliensis leaves were desiccated to a constant weight at room temperature while being protected from light. The dried material $(184 \mathrm{~g})$ was ground and then successively macerated with n-hexane (by two times) and EtOAc (by two times). In each maceration step, the material was kept in contact with the solvent for $72 \mathrm{~h}$. The extracts were concentrated using a rotary evaporator $\left(40-42^{\circ} \mathrm{C}\right.$ under reduced pressure) yielding $5.03 \mathrm{~g}$ of hexane extract $(2.73 \%$ yield $)$ and $4.99 \mathrm{~g}$ of EtOAc extract ( $2.71 \%$ yield).

The EtOAc extract was then resuspended in a water: $\mathrm{EtOH} \mathrm{(1:3)} \mathrm{mixture} \mathrm{was} \mathrm{successively}$ partitioned in $\mathrm{n}$-hexane and chloroform $\left(\mathrm{HCCl}_{3}\right)$, yielding $1.83 \mathrm{~g}$ of the hexane phase, $0.92 \mathrm{~g}$ of the $\mathrm{HCCl}_{3}$ phase, and $1.41 \mathrm{~g}$ of water-alcohol phase after solvent removal.

The hexane extract and $\mathrm{HCCl}_{3}$ phase of the EtOAc extract were fractionated by CC, and similar TLC fractions were pooled.

The fractionation of the hexane extract yielded 107 fractions of $25 \mathrm{~mL}$, which, once pooled, yielded 53 fractions. Of these, the EHE1 fraction (15 mg; eluted with 9:1 n-hexane:EtOAc), the EHE4 fraction (40 mg; eluted with n-hexane:EtOAc 8:2) and the EHE5 fraction (123 mg; eluted with n-hexane:EtOAc 7:3), when treated with n-hexane, yielded colorless solids (by precipitation), which were separated from the solution.

In turn, the fractionation of the $\mathrm{HCCl}_{3}$ phase yielded 234 fractions of $20 \mathrm{~mL}$, which were pooled together totaling 80 fractions. The treatment of the EAE1 fraction (50 mg; eluted with 7:3 $\mathrm{n}$-hexane:EtOAc) with $\mathrm{n}$-hexane provided a colorless solid, which was separated from the solution.

The extracted solids (EHE1, EHE4, EHE5, and EAE1 fractions) were analyzed by GC/MS, and nine chemical components were identified (1 to 9). The constituents denoted as (1), (3), (5), and (7) were identified in the solid obtained from the EHE1 fraction (besides the analysis on GC/MS, this material was also analyzed by $1 \mathrm{D}{ }^{1} \mathrm{H}$ and ${ }^{13} \mathrm{C}-\mathrm{NMR}$ and ${ }^{13} \mathrm{C}$-NMR-DEPT 135). The constituents (2), (4), and (6) were identified in the material obtained from the EHE4 fraction. The constituents (1), (4), (6), (8), and (9) were identified from the EHE5 fraction. The solid obtained from the EAE1 fraction was a mixture containing (1), (4), and (6).

\section{RESULT AND DISCUSSION}

\section{Qualitative analysis of the essential oil}

The composition of the essential oil obtained from the leaves of $P$. brasiliensis is summarized in Table 1; the constituents are listed according to their elution order through the Agilent $₫$ DB-5MS capillary column.

The majority of the constituents of the essential oil were identified, with 14 monoterpenes and 11 sesquiterpenes.

Considering the areas of their peaks in the chromatogram, monoterpenes a-pinene (32.61\%), $\alpha$-thujene $(17.21 \%)$, $\alpha$-phellandrene $(8.86 \%)$, $\beta$-pinene $(7.55 \%)$, sabinene (4.44\%), $E$ - $\beta$-ocimene $(4.15 \%)$, and sesquiterpene $E$-caryophyllene $(6.87 \%)$ were the most representative constituents. These results differ from a previous study that reported the predominance of terpinenes and terpineols (Silva et al., 2015). In the present study, we observed a low yield of essential oil in comparison with previous research (Silva et al., 2015). These differences in chemical composition and essential oil yield between samples from different studies occur by several factors, such as the biotic and abiotic factors of the geographic regions where the specimens are found, genetic characteristics, season in which the plant was collected, and plant growth and development (Gobbo-Neto \& Lopes, 2007).

As reported by Bohlmann et al. (1984) during their studies with the nonpolar extract of the above ground portions of $P$. brasiliensis, the terpenoids cadinene $(0.85 \%)$, and spathulenol $(0.46 \%)$ were also identified in the essential oil. On the other hand, the sesquiterpenes described in that study (hydroxygermacrene, cadinol, and oplopanone), which also can be present in essential oil, were not detected in the analyzed sample. This could be explained by genetic, ontogenetic, and environmental differences between the studied specimens (Sangwan et al., 2001; Gobbo-Neto \& 
TABLE 1. Terpenes identified by GC / MS in the essential oil of fresh leaves of $P$. brasiliensis.

\begin{tabular}{|c|c|c|c|}
\hline Constituents $^{*}$ & Relative area (\%) & RRI cal & RRI lit \\
\hline 1. $\alpha$-Thujene & 17.21 & 924 & 931 \\
\hline 2. $\alpha$-Pinene & 32.61 & 932 & 939 \\
\hline 3. N.I. & 0.18 & 939 & - \\
\hline 4. N.I. & 0.22 & 948 & - \\
\hline 5. Sabinene & 4.44 & 971 & 976 \\
\hline 6. $\beta$-Pinene & 7.55 & 977 & 980 \\
\hline 7. $\beta$-Myrcene & 3.22 & 987 & 991 \\
\hline 8. a-Phellandrene & 8.86 & 1007 & 1005 \\
\hline 9. $\alpha$-Terpinene & 0.08 & 1016 & 1018 \\
\hline 10. $p$-Cymene & 0.52 & 1023 & 1026 \\
\hline 11. Limonene & 3.41 & 1028 & 1031 \\
\hline 12. N.I. & 0.05 & 1030 & - \\
\hline 13. Z- $\beta$-Ocimene & 0.10 & 1033 & 1040 \\
\hline 14. E- $\beta$-Ocimene & 4.15 & 1044 & 1050 \\
\hline 15. $y$-Terpinene & 0.33 & 1056 & 1062 \\
\hline 16. $\alpha$-Terpinolene & 0.16 & 1084 & 1088 \\
\hline 17. N.I. & 0.17 & 1112 & - \\
\hline 18. a-Terpineol & 0.31 & 1179 & 1189 \\
\hline 19. $\delta$-Elemene & 0.13 & 1332 & 1339 \\
\hline 20. a-Copaene & 1.28 & 1372 & 1376 \\
\hline 21. E-Caryophyllene & 6.87 & 1415 & 1418 \\
\hline 22. N.I. & 0.23 & 1426 & - \\
\hline 23. a-Humulene & 0.15 & 1450 & 1454 \\
\hline 24. Germacrene D & 3.40 & 1476 & 1480 \\
\hline 25. Bicyclogermacrene & 1.54 & 1490 & 1494 \\
\hline 26. a-Muurolene & 0.19 & 1494 & 1499 \\
\hline 27. $\delta$-Cadinene & 0.85 & 1514 & 1524 \\
\hline 28. Germacrene B & 1.12 & 1552 & 1556 \\
\hline 29. Spathulenol & 0.46 & 1571 & 1576 \\
\hline 30. Caryophyllene oxide & 0.21 & 1576 & 1581 \\
\hline
\end{tabular}

Total identified constituents: $88.3 \%$ : $46.7 \%$ monoterpenes; $36.7 \%$ sesquiterpenes; $16,6 \%$ N.I.

RRI cal: Relative Retention Index calculated; RRI lit: Relative Retention Index from the literature; N.I.: not identified. * In order of elution

Lopes, 2007).

\section{Chemical constituents in the hexane and ethyl acetate extracts}

The chemical study of the hexane extract from leaves of $P$. brasiliensis resulted in the isolation and identification of the diterpene kaurenoic acid (1) and of the following triterpenes: $\alpha$-amyrin (2), $\alpha$-amyrin acetate (3), $\beta$-amyrin (4), $\beta$-amyrin acetate (5), lupeol (6), lupeol acetate (7), pseudotaraxasterol (8), and taraxasterol (9). In turn, from the EtOAc extract (chloroform phase), the secondary metabolites (1) (4), (6) were identified (Figure 1).

The identification of the structure in (1) was performed by MS and ${ }^{1} \mathrm{H}-\mathrm{NMR},{ }^{13} \mathrm{C}-\mathrm{NMR}\left(\left\{{ }^{13} \mathrm{C}\right\}\right.$ and DEPT). Compounds (2)-(9) were identified by MS and showed RRI by GC compatible with those of terpene standards, which assisted in their identification. Spectral data for the terpenes (1)-(9) were compared to literature data and are shown in Table 2. The calculated RRI of terpenes (2)-(9) and the RRI for the standards are shown in Table 3.

This is the first time that the presence of kaurenoic acid in $P$. brasiliensis has been reported. There are studies that indicate some activities for kaurenoic acid and derivatives: anticonvulsant, anticancer, anti-inflammatory, and others (Okoye et al., 2013; Lima Silva et al., 2015; Simão et al., 2016). Chemotaxonomic studies have indicated the presence of terpenes in the Asteraceae family, and 


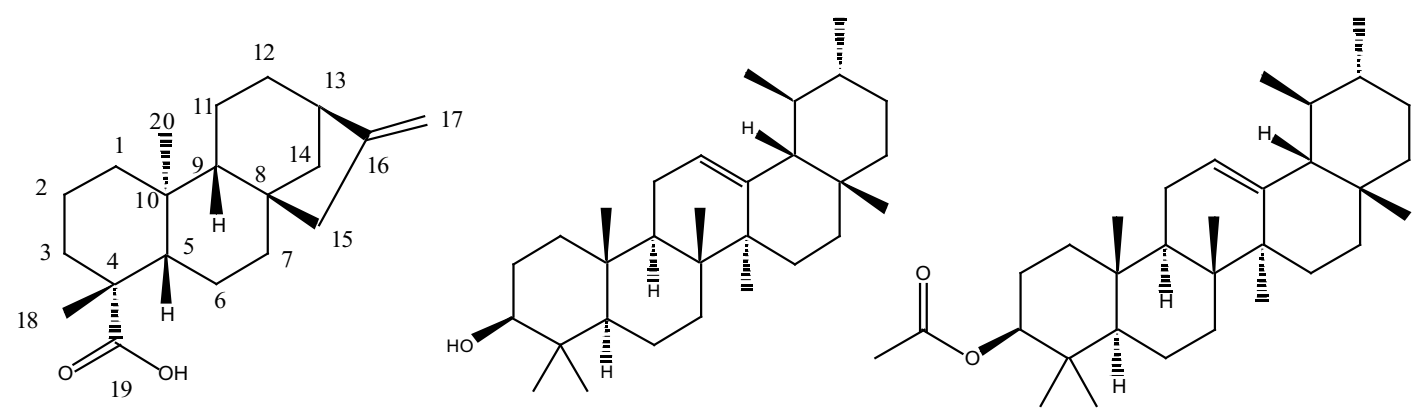

1

2

3

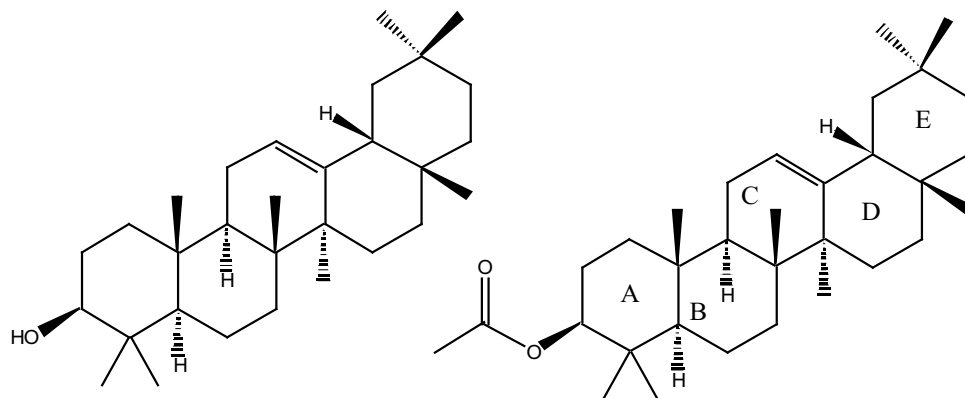

4
5<smiles>C=C(C)[C@@H]1CCC2(C)CC[C@]3(C)[C@H](CC[C@@]4(C)[C@@]3(C)CC[C@]3(C)C(C)(C)[C@@H](O)CC[C@@]34C)[C@]12C</smiles>

6

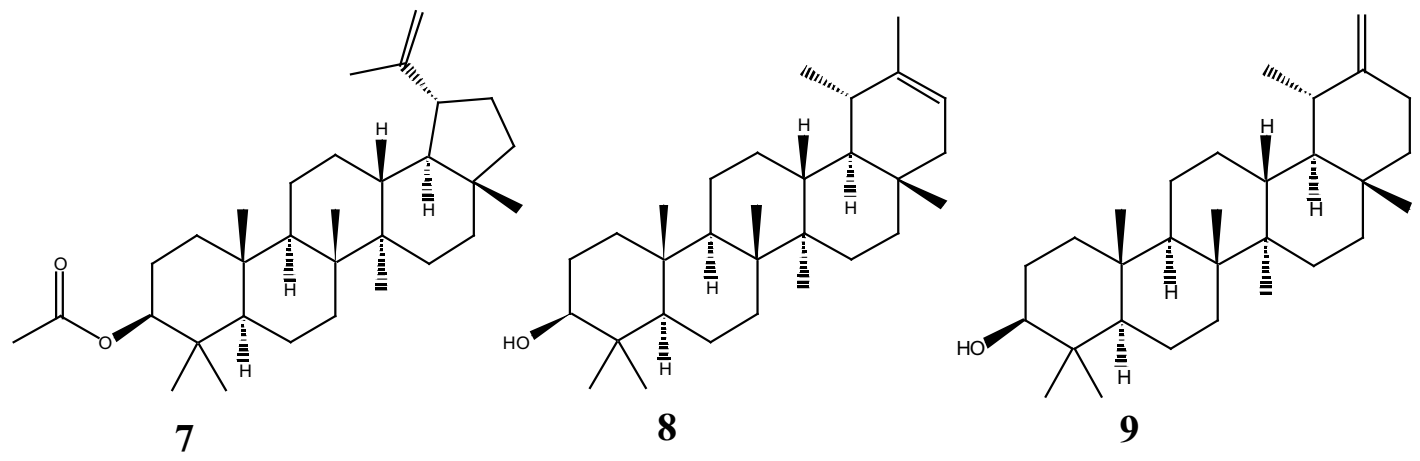

8

FIGURE 1. Terpenes identified in organic extracts (hexane and ethyl acetate) of the leaves of $P$. brasiliensis. 1: Kaurenoic acid; 2: $\alpha$-Amyrin; 3: $\alpha$-Amyrin acetate; 4: $\beta$-Amyrin; 5: $\beta$-Amyrin acetate; 6: Lupeol; 7: Lupeol acetate; 8: Pseudotaraxasterol; 9: Taraxasterol.

diterpenes with a kaurane skeleton was found in the Eupatorieae tribe (Alvarenga et al., 2005).

Triterpenes identified in this study with oleane, ursane, and lupeane skeletons are the characteristic of the family and are present in almost all of the tribes (Hegnauer, 1977; Zdero \& Bohlmann, 1990). $\beta$-amyrin and lupeol have been previously described in P. brasiliensis (Bohlmann et al. 1984).

$P$. brasiliensis can be considered a substitute for Asteraceae Arnica montana L. This species is native to Europe and is used to treat bruises, inflammation, and muscular and rheumatic pains, whereby helenalin-type sesquiterpene lactones are mainly responsible for the anti-inflammatory activity (Blumenthal et al., 1998; Merfort, 2011). Some terpenoids of $P$. brasiliensis may be responsible for its antiinflammatory activity, such as kaurenoic acid and the triterpenes lupeol, $\alpha$-amyrin, $\beta$-amyrin, and taraxasterol, which are identified in this study. This is possible because the anti-inflammatory activity has been reported for these triterpenes (Almeida et al., 2015; Piao et al., 2015; Zhu et al., 2016) and for the diterpene acid (Lima Silva et al., 2015). Furthermore, $\alpha$-pinene, $\beta$-pinene, myrcene, p-cymene, limonene and E-caryophyllene, among others present in the essential oil, are known for their anti-inflammatory activity, which may contribute to the use of the plant in popular medicine (Bonjardim et al., 2012; Woguem et al., 2014; Rufino et al., 2015).

$P$. brasiliensis is used in popular medicine. Since there are few studies about the plant, the data obtained in this study are a contribution to the knowledge of its chemical composition. Some compounds that may be related to the therapeutic use of the plant were identified; however, more phytochemical studies and research in pharmacological activity are needed to validate its use. 
TABLE 2. Spectral data of terpenoid in extracts (hexane and ethyl acetate) from the leaves of $P$. brasiliensis, compared with literature descriptions.

\begin{tabular}{|c|c|c|c|}
\hline \multirow{2}{*}{$\begin{array}{l}\text { Terpene } \\
\text { Kaurenoic acid }\end{array}$} & Spectrum & Relevant signals of the experimentally obtained spectra ${ }^{a}$ & \multirow{5}{*}{$\begin{array}{l}\text { Literature } \\
\text { Vilegas et al., } \\
\text { 1997; } \\
\text { Neto et al., } 2008 .\end{array}$} \\
\hline & ${ }^{1} \mathrm{H}-\mathrm{NMR}$ & $2.64(1 \mathrm{H})$ allylic hydrogen attached to carbon $\mathrm{C}-13$, characteristic of & \\
\hline \multirow[t]{11}{*}{ (1) } & & kaurene skeleton diterpenes. This structural type was confirmed by & \\
\hline & & the characteristic signals related to hydrogens $\mathrm{H}-18(1.24 ; \mathrm{s} ; 3 \mathrm{H}), \mathrm{H}-20$ & \\
\hline & & (0.95; s; 3H), $\mathrm{H}-17$ (4.80; s; $1 \mathrm{H})$, and $\mathrm{H}-17$ (4.74; s; $1 \mathrm{H})$. & \\
\hline & ${ }^{13} \mathrm{C}-\mathrm{NMR}$ & $183.6=$ carboxyl group $(\mathrm{C}-19) ; 155.3(\mathrm{C}-16)$ and $102.4(\mathrm{C}-17)$, related & \\
\hline & & to the exocyclic double bond of the kaurene skeleton; and 56.4 (C-5) & \\
\hline & & $=$ trans-axial location between the carboxyl group and the $\mathrm{H}-5$. & \\
\hline & DEPT 135 & Signals corresponding to 2 methyl carbons (C-18 and C-20), 10 & \\
\hline & & methylene carbons, 3 methine carbons $(C-5, C-9, C-13)$ and 5 non- & \\
\hline & & hydrogenated carbons. & \\
\hline & & $302\left(\mathrm{M}^{+}\right), 287\left(\mathrm{M}^{+}-\mathrm{CH}_{3}\right),\left[\right.$ Remark 3] 259, $241\left(\mathrm{M}^{+}-\mathrm{CH}_{3}\right.$ and $\left.-\mathrm{HCOO}\right)$ & \\
\hline & MS & $148,121\left(\mathrm{C}_{9} \mathrm{H}_{13}{ }^{+}\right), 109,105\left(\mathrm{C}_{8} \mathrm{H}_{9}^{+}\right), 91$ (tropylium ion) [100\%] & \\
\hline a-Amyrin (2) and & MS & $426\left(\mathrm{M}^{+}\right), 218$ (fragment from Diels-Alder retro rearrangement: $A$ and & \\
\hline \multirow[t]{2}{*}{$\beta$-Amyrin (4) b } & & $B+$ rings part of $C$ or D and E rings + part of C) [100\%], $203(218$ & Silva et al., 1998; \\
\hline & & $-\mathrm{CH}_{3}$ fragment). & Jeong \& Lachance, \\
\hline$\alpha$ - Amyrin acetate (3) and & MS & $468\left(\mathrm{M}^{+}\right), 218$ (fragment from Diels-Alder retro rearrangement) & 2001. \\
\hline$\beta$-Amyrin acetate $(5) \circ$ & & [100\%], $203\left(218-\mathrm{CH}_{3}\right.$ fragment $)$ & \\
\hline \multirow[t]{2}{*}{ Lupeol (6), } & MS & $426\left(M^{+}\right), 203(D$ and $E$ rings + part of C), 189(characteristic of lupane & \\
\hline & & skeleton). & \\
\hline Lupeol acetate (7) & & $468\left(\mathrm{M}^{+}\right), 189$ & \\
\hline Pseudotaraxasterol (8) and & MS & $426\left(\mathrm{M}^{+}\right), 189[100 \%]$ & \\
\hline Taraxasterol $(9)^{\mathrm{d}}$ & & & \\
\hline
\end{tabular}

a Mass spectra fragments: $m / z$; NMR spectra: $\delta_{H}$ and $\delta_{C}$ in ppm and $s=$ singlet . blsomers : ursene (2) and oleanene (4) skeletons. clsomers: ursene (3) and oleanene (5) acetylated. dPositional isomers: urs-20-ene (8) and urs-20 (30)-ene (9)

TABLE 3. Terpenes identified in fractions of the organic extracts (hexane and ethyl acetate) of the leaves of $P$. brasiliensis.

\begin{tabular}{|c|c|c|c|c|}
\hline Fraction & Terpene & Area (\%) & RRI cal & RRI stan \\
\hline \multirow[t]{4}{*}{ EHE1 } & Kaurenoic acid & 77.09 & 0.7891 & - \\
\hline & $\beta$-Amyrin acetate & 3.34 & 2.2977 & 2.305 \\
\hline & a-Amyrin acetate & 2.19 & 2.4736 & 2.471 \\
\hline & Lupeol acetate & 4.86 & 2.5022 & 2.505 \\
\hline \multirow[t]{3}{*}{ EHE4 } & $\beta$-Amyrin & 8.20 & 2.1818 & 2.184 \\
\hline & a-Amyrin & 8.03 & 2.3706 & 2.370 \\
\hline & Lupeol & 29.73 & 2.3889 & 2.390 \\
\hline \multirow[t]{5}{*}{ EHE5 } & Kaurenoic acid & 3.18 & 0.7914 & - \\
\hline & $\beta$-Amyrin & 16.31 & 1.3368 & 1.334 \\
\hline & Lupeol & 47.48 & 1.3854 & 1.383 \\
\hline & Pseudotaraxasterol & 0.50 & 1.4835 & 1.480 \\
\hline & Taraxasterol & 0.83 & 1.4977 & 1.494 \\
\hline \multirow[t]{3}{*}{$\mathrm{AE} 1$} & Kaurenoic acid & 25.01 & 0.7970 & - \\
\hline & $\beta$-Amyrin & 0.25 & 1.3324 & 1.334 \\
\hline & Lupeol & 0.96 & 1.3801 & 1.383 \\
\hline
\end{tabular}

Area: relative peak area in the chromatogram; RRI cal: Relative Retention Index calculated; RRI stan: Relative Retention Index standards of terpenes.

Rev. Bras. PI. Med., Campinas, v.18, n.2, p.408-414, 2016. 


\section{ACKNOWLEDGMENTS}

The authors are grateful to Prof. Dr. Norberto Peporine Lopes and Izabel Cristina Casanova Turatti (NPPNS/FCFRP-USP) for analysis on GC/MS; the Prof. Dr. Roqueline Silva Rodrigues de Miranda (Department of Chemistry/ UFMG) by NMR analyzes; CAPES scholarship; FAPEMIG for financial support analysis of essential oil (APQ-01104-11).

\section{REFERENCES}

ADAMS, R.P. Identification of essential oils components by gas chromatography/mass spectroscopy. $4^{\text {th }}$ ed. Carol Stream, Illinois, USA: Allured Publishing, 2001. 804p.

ALMEIDA, A.M. et al. Geographical distribution of Eupatorieae (Asteraceae) in South-eastern and South Brazilian Mountain Ranges. Plant Ecology, v.174, n.1, p.163-81, 2004.

ALMEIDA et al. Anti-inflammatory activity of triterpenes isolated from Protium paniculatum oil-resins. EvidenceBased Complementary and Alternative Medicine, v.2015. p.1-10, 2015.

ALVARENGA, A.S.V. et al. A general survey and some taxonomic implications of diterpenes in the Asteraceae. Botanical Journal of the Linnean Society, v.147, n.3, p.291-308, 2005.

BABUSHOK, V.I.; ZENKEVICH, I.G. Retention indices for most frequently reported essential oil compounds in GC. Chromatographia v.69, n.3-4, p.257-69, 2009.

BLUMENTHAL, M. et al. The Complete German Commission E Monographs: Therapeutic Guide to Herbal Medicines. Austin, Texas: American Botanical Council. Boston, Massachusetts, Integrative Medicine Communication, 1998. 201p.

BOHLMANN, F. et al. Hydroxygermacrene and other constituents from Pseudobrickellia brasiliensis. Phytochemistry, v.23, n.8, p.1798-9, 1984.

BONJARDIM, L.R. et al. Evaluation of the anti-inflammatory and antinociceptive properties of p-cymene in mice. Zeitschrift für Naturforschung C, v.6, n.1, p.15-21, 2012.

FORZZA, R.C. et al. Catálogo de Plantas e Fungos do Brasil - vol. 1. Rio de Janeiro: Instituto de Pesquisas Jardim Botânico do Rio de Janeiro, Andrea Jakobsson Estúdio, 2010. 871p.

GOBBO-NETO, L.; LOPES, N.P. Plantas medicinais: fatores de influência no conteúdo de metabólitos secundários. Química Nova, v.30, n.2, p.374-81, 2007.

GONÇALVES, L.D. et al. Contribution for the phytochemical studies of Ageratum fastigiatum. Revista Brasileira de Farmacognosia, v.21, n.6, p.936-42, 2011.

HEGNAUER, R. The chemistry of the Compositae. In: HEYWOOD, V.H.; HARBORNE, J.B.; TURNER, B.L. (Eds). The biology and chemistry of the Compositae - v. 1. 1.ed. London: Academic Press Inc Ltd, 1977. p. 283-335.

JEONG, W.S.; LACHANCE, P.A. Phytosterols and fatty acids in fig (Ficus carica, var. mission) fruit and tree components. Food and Chemical Toxicology, v.66, p.278-81, 2001.

LIMA SILVA, J. et al. Effects of kaurenoic acid and arginine on random skin flap oxidative stress, inflammation, and cytokines in rats. Aesthetic Plastic Surgery, v.39, n.6, p.971-7, 2015.

MERFORT, I. Perspectives on Sesquiterpene Lactones in Inflammation and Cancer. Current Drug Targets, v.12, n.11, p.1560-73, 2011.

NETO, J.S.L. et al. Constituintes químicos dos frutos de Copaifera langsdorffii Desf. Química Nova, v.31, n.5, p.1078-80, 2008.

OKOYE, T.C. et al. Anticonvulsant effect of kaurenoic acid isolated from the root bark of Annona senegalensis. Pharmacology, Biochemistry and Behavior, v.109, p.38-43, 2013

PIAO, T. et al. Taraxasterol inhibits IL-1 $\beta$-induced inflammatory response in human osteoarthritic chondrocytes. European Journal of Pharmacology, v.756, p.38-42, 2015.

RIBEIRO, J.F. et al. Caracterização Florística e Potencial de Uso das Espécies Vasculares Ocorrentes nas Fazendas Trijunção, BA - Documentos v.46. 1.ed. Planaltina, DF: Publicação Embrapa Cerrados, 2001. $48 p$.

RUFINO, A.T., et al. Evaluation of the anti-inflammatory, anticatabolic and pro-anabolic effects of E-caryophyllene, myrcene and limonene in a cell model of osteoarthritis. European Journal of Pharmacology, v.750, p.141-150, 2015.

SANGWAN, N.S. et al. Regulation of essential oil production in plants. Plant Growth Regulation, v.34, n.1, p.3-21, 2001.

SILVA, J.R.A. et al. Ésteres triterpênicos de Himatanthus sucuuba (Spruce) Woodson. Química Nova, v.21, n.6, p.702-4, 1998.

SILVA, R.F. et al. 2015. Scents from Brazilian Cerrado: chemical composition of the essential oil from Pseudobrickellia brasiliensis (Asteraceae). Journal of Essential Oil Research, v.27, n.5, p.417-20, 2015.

SIMÃO, M. et al. In vitro cytotoxicity study of ent -kaurenoic acid derivatives against human breast carcinoma cell line. Medicinal Chemistry Research, v.25, n.2, p.3039, 2016.

VAN DEN DOOL, H.; KRATZ, P.D. A generalization of the retention index system including linear temperature programmed gas-liquid partition chromatography. Journal of Chromatography A, v.11, p.463-71, 1963.

VILEGAS, J.H.Y. et al. Extraction of low-polarity compounds (with emphasis on coumarin and kaurenoic acid) from Mikania glomerata ('guaco') leaves. Phytochemical Analysis, v.8, n.5, p.266-70, 1997.

WOGUEM, V. et al. ; Volatile oil from striped african pepper (Xylopia parviflora, Annonaceae) possesses notable chemopreventive, anti-inflammatory and antimicrobial potential. Food Chemistry, v.149, p.183-9, 2014.

ZDERO, C.; BOHLMANN, F. Systematic and evolution within the Compositae seen with the eyes of a chemistry. Plant Systematics and Evolution, v.171, n.1-4, p.114, 1990.

ZHU, Y. et al. The pentacyclic triterpene Lupeol switches M1 macrophages to M2 and ameliorates experimental inflammatory bowel disease. International immunopharmacology, v.30, p.74-84, 2016. 